\title{
Legal issues in the field of digital technologies in Russia
}

\author{
Yuliya Isakova $^{1}$ and Evgeny Millerov ${ }^{1}, 2 *$ \\ ${ }^{1}$ Don State Technical University, 344000, Rostov-on-Don, Russia \\ ${ }^{2}$ South-Russian State Institute of Management - branch of the Russian Presidential Academy of the \\ National Economy and Public Administration, 344002, Rostov-on-Don, Russia
}

\begin{abstract}
The article examines the negative factors of the impact of the Internet on the moral development of minors (that is, persons under the age of eighteen), the legal aspects of countering these factors. The types of information on the Internet are analyzed, which can harm children to their moral development. In addition to the study of laws that are exclusively regulatory in nature of these issues, the main emphasis is placed on the analysis of the norms of the Code of Administrative Offenses of the Russian Federation and the Criminal Code of the Russian Federation, which provide for legal liability for acts that are capable for causing harm to minor Internet users. Some problems of classification of these administrative offenses and crimes are considered, the position of the Supreme Court of the Russian Federation is given, the official statistics of the Ministry of Internal Affairs of Russia are analyzed with ocular demonstration. At the end of the study, the authors put forward their own conclusions regarding the legal aspects of the protection of minor Internet users, and proposals are also made for amending some norms of the Code of Administrative Offenses of the Russian Federation and the Criminal Code of the Russian Federation.
\end{abstract}

\section{Introduction}

Morality is one of the most important objects of legal protection, which is mentioned even in the Constitution of the Russian Federation (Article 55). It is no secret that children are actively using the Internet nowadays. In addition to the positive aspects of this network regarding them (cultural factors, use in the educational process, etc.), there are also negative aspects, in particular, those that can harm their moral development.

The purpose of this study is to identify the negative aspects of the impact of the Internet on the moral development of minors, as well as the legal characteristics and problems of counteracting this factor. To achieve this goal, the following tasks have been set: study of the legal mechanism for protecting the moral development of minors; analysis of the norms providing for administrative and criminal liability for illegal acts infringing on the morality of minors on the Internet.

\footnotetext{
*Corresponding author: evgenijj-millerov@rambler.ru
} 


\section{Materials and methods}

This study analyzes a substantial number of various scientific works related to the protection of the morality of minors. There is an analysis of judicial practice, including the Supreme Court of the Russian Federation on the classification of unlawful acts, statistical indicators of the Ministry of Internal Affairs of Russia. Within the framework of the study, the following methods of scientific knowledge were used: formal-logical, comparativelegal, statistical, etc.

\section{Results}

According to the authors of some studies, familiarizing children with the Internet can generate a number of negative consequences [1]. Within the framework of this study, we are interested in what problems the Internet carries for the moral development of minors and what legal norms are in Russian legislation to counter this.

Exploring the legal mechanism for protecting the moral development of minors, first of all, mention should be made of the Federal Law of 24.07.1998 No. 124-FZ "On the Basic Guarantees of Children's Rights in the Russian Federation". To understand what information can harm the moral development of minors, you should familiarize yourself with the Federal Law of 29.12.2010 No. 436-FZ "On Protection of Children from Information Harmful to their Health and Development".

According to this Russian law, all information that is negative for minors, is divided into prohibited and limited one. Without listing here all the types of information prohibited for dissemination among minors, we will identify only those that clearly harm moral development. Based on the analysis of Part 2 Article 5 of the said law, these types are: information that may cause children to desire to engage in prostitution; information that justifies violence and cruelty both in relation to humans and in relation to animals; information denying family values, promoting non-traditional sexual relations, forming a disrespectful attitude towards their parents and other family members; information containing obscenities; information containing pornography.

Those types of information that have certain restrictions on its dissemination among minors are listed in Part 3 Article 5 of the above law. These types of information can be disseminated among minors only in compliance with the age categories provided for in Articles 7-10 of this regulatory legal act. The age categories of minors are the following: under the age of 6 ; have reached the age of 6 ; have reached the age of 12 ; have reached the age of 16.

For a complete understanding of morality as an object of legal protection (including with respect to minors), one should refer to the Code of the Russian Federation on Administrative Offenses and the Criminal Code of the Russian Federation.

Administrative offenses that infringe on morality are located in Chapter 6 of the Code of Administrative Offenses of the Russian Federation. Such offenses include acts related to prostitution (Article 6.11) and income from prostitution by another person (Article 6.12), violation of the rules for disseminating information among minors (Article 6.17), production and circulation by a legal entity of materials with a pornographic image of minors (Article 6.20), promotion of non-traditional sexual relations among minors (Article 6.21), organization of a public event (performance, concert, etc.) containing obscenities (Article 6.26), violation of rules for distribution of printed and audiovisual products containing obscenities (Article 6.27 ).

It should be noted that the range of these norms has been supplemented by Russian legislators in the past few years. All of them were introduced into the Code of Administrative Offenses of the Russian Federation within the period from 2010 to 2020, 
with the exception of Articles 6.11 and 6.12, which were still in its original version in this Code.

The analysis of these articles of the Code of Administrative Offenses of the Russian Federation suggests that in some of them it would be advisable to establish stricter administrative responsibility for the actions described in them "using the mass media, including information and telecommunication networks (including "Internet")", to wit in Article 6.20 of this Code.

The crimes interfering with morality are located in Chapter 25 of the Criminal Code of the Russian Federation. These include offenses provided for in Articles 240-245 of this Code (that is, crimes related to the organization of the rendering the sexual services, the production and distribution of pornography, encroachment upon cultural heritage resources, abuse of corpses and their burial places, cruelty to animals).

It should be noted that the dissemination of information among minors that could harm their moral development using the Internet, is currently mainly assessed as an aggravating factor in the Criminal Code of the Russian Federation, but not always, in this regard, now, about this problem in details.

The legal analysis of the problems of classification of crimes that we are considering will begin with Article 135 of the Criminal Code of the Russian Federation. First of all, it shall be said that this norm, which provides for criminal liability for indecent acts against persons under the age of 16 , does not apply formally to the elements of crimes that infringe on morality, since it is stipulated not in Chapter 25 of the Code, but in Chapter 18 (that is, to crimes that infringe on sexual freedom and sexual inviolability). At the same time, the nature of this crime is such that it is closer to crimes against morality. In this regard, even some legal scholarship speaks out about the advisability of transferring Article 135 from Chapter 18 to Chapter 25 of the Criminal Code of the Russian Federation. Sexual abuse acts, based on the disposition of Article 135, consist in any actions of a sexual nature, with the exception of sexual acts.

Dissemination of information about non-traditional sexual relations among minors can constitute a crime under article 135 of the Criminal Code of the Russian Federation (sexual abuse acts). At the same time, it should be noted that informing minors about nontraditional sexual relations should not always be assessed as a criminal act provided for in Article 135 of the Criminal Code of the Russian Federation, since there may be an administrative offense under Article 6.21 of the Code of Administrative Offenses of the Russian Federation. (promotion of non-traditional sexual relations among minors). What this administratively punishable propaganda consists of is described in detail and clearly in the disposition of Article 6.21 of this Code. The main criterion that distinguishes these administratively punishable acts from criminally punishable sexual abuse acts, in our opinion, is, in fact, that such propaganda is not aimed at one or only specific few persons of a minor age. Another important consideration is that Article 6.21 of this Code is aimed only at focusing the attention of minors on "non-traditional sexual relations", while criminal offenses do not have such an exclusive purpose under Article 135 of the Criminal Code of the Russian Federation.

Unlike administratively punishable, under Article 135 of the Criminal Code of the Russian Federation in accordance with the explanations given in paragraph 17 of one of the resolutions of the Plenum of the Supreme Court of the Russian Federation04.12.2014 No. 16 "On judicial practice in cases of crimes against sexual inviolability and sexual freedom of the individual", sexual abuse acts are any actions aimed at achieving sexual satisfaction of the guilty or at sexual excitement of the injured or his/ her interest in sexual relations (with the exception of sexual relationship, pederasty and lesbian acts) committed against minors in the age limit specified by this criminal legal provision. It is important to note the position of the Supreme Court of the Russian Federation, according to which such depraved 
actions can also be actions committed by a guilty person without physical contact with an injured minor, namely, such actions can be performed via the Internet or some other information and telecommunication networks, which, in fact, is also said in the above document. The absence in Article 135 of the Criminal Code of the Russian Federation of aggravating criminal liability signs for sexual abuse of any minor injured via the Internet is, in our opinion, a gap in this legal norm that needs to be filled. It seems that, based on the current structure of this article, it would be most successful to provide for liability precisely for such criminal acts in Part 3 Article 135 of this Code.

Among the information prohibited among minors, as we have already said here, there is information that can induce prostitution and pornographic information. The prohibition on recruiting children into prostitution and pornography is spelled out in a number of international multilateral treaties, in particular the Convention on the Rights of the Child (approved by the UN General Assembly on 20.11.1989), Convention on the Protection of Children against Sexual Exploitation and Sexual Abuse (CETS No. 201, Lansarote, 25.10.2007), Convention on Computer Crime (ETS No. 185, Concluded in Budapest on November 23, 2001).

Involvement in prostitution, probably, without exaggeration, can be called one of the most socially dangerous crimes against public morality provided for by the existing Criminal Code of the Russian Federation, especially when such a criminal act is committed with the use of violence, and even in relation to minors, as we already discussed earlier in one of our publications devoted to this issue [2]. Many scientists from various foreign countries speak about the problem of child prostitution and the need to combat it in their scientific works $[3,4,5]$.

Speaking more specifically about this issue in relation to minors, then the involvement of such persons in prostitution is punished by the Criminal Code of the Russian Federation much more severely (Part 3 Article 240) than an adult (Part 1 Article 240). The methods of involvement are not stipulated in Article 240, therefore it is considered a criminal offense to involve a minor in prostitution in any way. At the same time, Article 240 does not provide among the aggravating signs of involvement in prostitution using the Internet, which, according to some authors [6], is a serious omission of legislators, because today there are facts of involvement of persons (including minors) into engaging in this activity precisely through the Internet. Some experts in their writings call the provision of prostitution services via the Internet as "delocalized prostitution" [7].

As we noted above, pornography also belongs to one of the types of information that negatively affects the development of minors, therefore, the distribution of pornographic materials among persons under the age of 18 in Russia is punished more strictly by the Criminal Code of the Russian Federation (Part 2 Article 242), rather than the distribution of such materials among adults (Part 1 Article 242). In fairness, it shall be said that Part 2, which provides for stricter criminal liability for the distribution of pornography among minors, was not in the original version of this Code; it appeared in February 2012. Development and popularization of the Internet has created a real problem of free access of minors to pornographic sites, therefore, in Part 3, that was also supplemented in February 2012, Article 242 today provides for the strictest responsibility for the distribution of pornographic materials in the Internet (Clause b Part 3 Article 242).

The involvement of minors in the production of pornography is also a great problem. In our time, this problem has been intensified by the Internet, through which not only pornographic materials with images of children are distributed, but also children themselves are involved in the production of such materials. This problem is fairly discussed in the scientific works of authors from different countries and publications [8, 9, 10, 11]. Pornographic materials depicting minors are now commonly called "child pornography", and in some sources even "pedopornography" [12]. Often, the involvement of children in 
these activities occurs via the Internet, as well as the largest number of photos and videos produced with pornographic images of children are also distributed through this network. Therefore, some authors call such pornographic materials "cyber - child pornography" [13]. In Russia, they became concerned about strengthening the fight against trafficking in child pornography using criminal law at the beginning of this century. In December 2003, Article 242.1 was included in the Criminal Code of the Russian Federation, which acts as a special rule in relation to Article 242 and provides for stricter liability for the production and circulation of pornographic materials depicting minors. In February 2012, this Code was also supplemented by Article 242.2, which criminalizes the use of a minor for the production of pornographic materials.

The development of computer technology in recent years has given rise to this kind of pornography, which is actually called virtual. It is called in that way due to the fact that it is completely generated by programming (i.e. people do not participate in its generation as porn actors). Some authors raise the question of the need to include a separate article in the Criminal Code of the Russian Federation, which would provide for liability for such pornography [14]. We believe that there is no such need, since the range of the above criminal legal provisions, in our opinion, makes it possible to objectively classify all socially dangerous acts associated with the circulation of pornography. Moreover, the direct answer to the question is this or that material (the information available in it or on it) or the subject is pornographic, it is not the person who investigates such a criminal case that is responsible, but the relevant experts who conduct appropriate examinations on such criminal cases (as a rule, complex), without which criminal cases on the facts of illegal traffic in pornography today in Russia are simply not sent to the courts (this is already a fairly long-established practice in such cases in our country). In this regard, in our opinion, the classification of such acts in the event of the appearance of "virtual pornography" does not cause a serious problem. The material is pornographic or not, regardless of whether it depicts real people, or the material is made exclusively with the use of computer graphics. Therefore, we do not believe that a separate norm for the classification of "virtual pornography" is required. Another thing is that the establishment during the investigation of a criminal case of the fact of making just such ("virtual") pornography depicting a minor will affect the classification of such a crime, namely, these actions will be correctly classified only under Article 242.1 of the Criminal Code of the Russian Federation, Article 242.2 , since a real minor was not used in the production of this pornographic material.

The analysis of the official statistics of the Ministry of Internal Affairs of Russia for 2020 (Figure 1), taken from the website of this department (The state of crime in Russia (January-December 2020) // Ministry of Internal Affairs of Russia / Main Information and Analysis Center - https: //mvd.rf) suggests that the entire mass of crimes committed in our country using the Internet $(300,337)$, crimes related to the distribution of pornography on the Internet (that is, acts provided for in Articles 242, 242.1 and 242.2 of the Criminal Code of the Russian Federation) are 2,099 cases. If we consider that the rest of the crimes of this statistical factor represents all other crimes that are committed using the Internet, then this is not so little.

Some authors combined all crimes that infringe on sexual freedom and sexual inviolability of the person together with criminal acts infringing on public morality in the field of sexual relations, which can be committed today using information and telecommunication networks (including the Internet) in order to develop a single the forensic model of their identification and investigation was combined into a group called "porn sexual cybercrimes" [15]. Perhaps this is really the right way to effectively identify, to solve and investigate such crimes. 


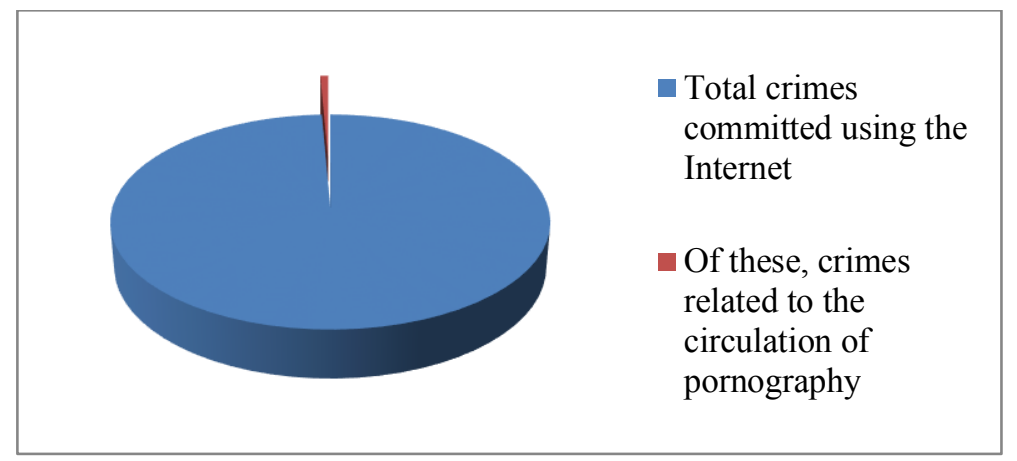

Fig.1. Quantitative ratio of crimes related to the circulation of pornography in the Internet in comparison with the total number of crimes committed using the Internet in Russia in 2020 (data from the website of the Ministry of Internal Affairs of Russia: https:/Мвд.рф)

\section{Discussion}

Within the framework of this study, the importance of the effectiveness of legal regulation of the peculiarities of the use of information distributed on the Internet by minors in order to protect their moral development is shown. This study, in our opinion, has shown that one of the most effective legal means of protecting the moral development of children when using the Internet is the norms that provide for legal liability against persons who violate the rules for the dissemination of negative information on this network, namely, the norms that provide for administrative and criminal liability. We believe that the legal mechanism for protecting the moral development of minors in Russia today is quite developed. This study showed that it contains both laws with regulatory norms and norms that provide for administrative and criminal liability for violations of public morality, including the moral development of minors, which, according to the analysis of these norms conducted above, are located in the Code of Administrative Offenses of the RF and the Criminal Code of the RF.

Within the framework of this study, it was found that in Russia, information prohibited for distribution among minors that can harm their moral development includes information that: can cause children to want to engage in prostitution; justifies violence and cruelty both towards people and animals; denies family values; promotes non-traditional sexual relations; forms a disrespectful attitude towards their parents and other family members; contains obscene language; contains pornography.

The dissemination of such information among children on the Internet is the greatest harm to their moral development, given the scale and accessibility of this network, so such facts are punished more severely both by articles of the Code of Administrative Offenses of the RF and by articles of the Criminal Code of the RF. At the same time, some of these articles in the framework of this study have identified some gaps that require legislative filling.

\section{Conclusions}

As a result of the study, the following conclusions and suggestions can be drawn:

1. The negative impact on the moral development of minors on the Internet can be expressed in two main types of negative and even dangerous consequences:

- negative impact on the normal moral development of minors; 
- commission of illegal acts against minors using the Internet that infringe on public morality (acts provided for by Chapter 6 of Code of Administrative Offenses the RF, Chapter 25 of the Criminal Code of the RF).

2. The legal mechanism for protecting the moral development of minors, including when they use the Internet, is sufficiently developed and multifaceted. today in Russia. An active rule-making period for improving this legal mechanism falls on the period 20102020. A special role in this legal mechanism is played by the norms of the Code of the Russian Federation on Administrative Offenses and the norms of the Criminal Code of the Russian Federation analyzed in this study.

3. It is necessary to supplement the aggravating factor "using the media, including information and telecommunication networks (including the Internet)" Article 6.20 of the Code of Administrative Offenses of the RF, Articles 135, 240 of the Criminal Code of the RF.

\section{References}

1. A. Asam, M. Samara, P. Terry, Addictive Behaviors 90, 428-436 (2019)

2. O.P. Gribunov, G.G. Nebratenko, E.V. Bezruchko, E.A. Millerova, All-Russian criminological journal 6(13), 941-950 (2019)

3. C. Hounmenou, Child Abuse \& Neglect 59, 26-35 (2016)

4. S. Siringi, The lancet 359, 1756 (2002)

5. W.J. Newman, B.W. Holt, J.S. Rabun, G. Phillips, C.L. Scott, International Journal of Law and Psychiatry 34(2), 116-121 (2011)

6. E.V. Bezruchko, E.V. Millerov, G.G. Nebratenko, All-Russian criminological journal 6(14), 878-879 (2020)

7. Ballester Brage L., Pozo Gordaliza R, Orte Socías C., Journal Procedia - Social and Behavioral Sciences 161, 90 (2014)

8. J. Prichard, P.A. Watters, C. Spiranovic, Computer Law \& Security Review 27(6), 585-600 (2011)

9. H. Temporini, Psychiatric Clinics of North America 35(4), 821-835 (2012)

10. J. Wolak, M. Liberatore, Neil Levine B., Child Abuse \& Neglect 38(2), 347-356 (2014)

11. K. Mitchell, J. Wolak, D. Finkelhor, Journal of Adolescent Health 40(2), 116-126 (2007)

12. G. Niveau, Journal Child Abuse \& Neglect 34, 570 (2010)

13. B. Schell, M. Martin, P. Hung, L. Rueda, Journal Aggression and Violent Behavior 12, 45 (2007)

14. O.V. Beschastnova, Humanitarian research 3(51), 181-182 (2014)

15. O.Yu. Antonov, Crime investigation: problems and solutions 3(17), 170 (2017) 